\title{
MOLECULAR CHARACTERIZATION AND IMMUNOPROTECTIVE ACTIVITY OF CAPSULAR POLYSACCHARIDE OF KLEBSIELLA PNEUMONIAE ISOLATED FROM FARM ANIMALS AT TAIF GOVERNORATE
}

\author{
${ }^{1}$ Ahmed M.A. Mansour, ${ }^{1,2}$ Hoda M. Zaki, ${ }^{1,3}$ Nibal A. Hassan and ${ }^{1}$ Abdulrahman A. Al-Humiany \\ ${ }^{1}$ Department of Medical Laboratory, Faculty of Applied Medical Sciences, Taraba, Taif University, KSA \\ ${ }^{2}$ Department of Brucella, Animal Health Research Insitute, Dokki, Giza, Egypt \\ ${ }^{3}$ Department of Pathology of Reproduction, Animal Reproduction Research Insitute, El-Harm, Giza, Egypt
}

Received 2013-12-21; Revised 2014-01-06; Accepted 2014-01-06

\begin{abstract}
Klebsiella pneumoniae is a Gram-negative enterobacterium that has historically been and currently remains, a significant cause of human disease and several kinds of infections in animals. In the present work, trials for the isolation of Klebsiella pneumoniae from diseased and apparently healthy farm animals (cows, sheep, goats and camels) were done for recognition of Klebsiella pneumoniae subspecies. It was noticed that there was a marked variation between incidences of Klebsiella pneumoniae subspecies in examined animals as regards to health condition. The frequency was greater among samples collected from diseased animals $25.2 \%$ as compared with apparently healthy one 5.5\%. It was found that there was great difference between the prevalence of Klebsiella isolated from various animal origins. On biochemical identification Klebsiella pneumoniae subsp. pneumoniae was the most prevalent followed by Klebsiella pneumoniae subsp. ozaenae and Klebsiella pneumoniae subsp. Rhinoscleromatis. Klebsiella pneumoniae subsp. rhinoscleromatis was not isolated from apparently healthy animals. The in vitro sensitivity of isolates of Klebsiella pneumoniae subspecies recovered from different animal species to 23 antimicrobial agents was tested. It was found that were resistance to cefoxitin, cefotaxime, cefoperazone, ceftazidime, ceftriaxone, aztreonam, amoxicillin and ampicillin. The most potent antibiotics showing $100 \%$ activity against Klebsiella pneumoniae subsp. isolated in this study were imipenem, ciprofloxacin, norfloxacin, gentamicin and kanamycin. While $96.2 \%$ of all examined isolates were sensitive to amoxicillin/clavulanic acid and ticarcillin/clavulanic acid. SDS-PAGE analysis showed that CPSs of Klebsiella pneumoniae subspecies contained wide variety of different molecular weights which ranged from $15.52 \mathrm{kDa}$ to106.29 $\mathrm{kDa}$ and gave 10-13 bands. Evaluation of humoral immune response of mice immunized with CPSs was done using ELISA. It was found that the highest immune response was obtained 14 days post 1 st dose of immunization with extracted CPSs of the three Klebsiella pneumoniae subspecies. When mice were immunized with CPSs of Klebsiella pneumoniae subspecies, they were protected against virulent challenge with homologous or heterologous strains, as a result the mortality rates were reduced from 80,75 and 65 to 5 to $15 \%$ of Klebsiella pneumoniae subsp. pneumoniae, Klebsiella pneumoniae subsp. ozaenae and Klebsiella pneumoniae subsp. rhinoscleromatis, respectively. Determination of the reisolation rates of Klebsiella pneumoniae subspecies from lung, liver and spleen were done on both immunized mice and challenged and on control mice. Histopathological studies have been done on both dead infected non-immunized and immunized mice. Lungs were the main organs that showed macroscopic and microscopic pathological changes. Finally, ELISA has been used for detection of CPSs of Klebsiella pneumoniae subspecies antibodies in sera of examined animals. The sensitivity of ELISA using CPSs extracted from Klebsiella pneumoniae subsp. pneumoniae, Klebsiella pneumoniae subsp. ozaenae and Klebsiella pneumoniae subsp. rhinoscleromatis was $87.7,89.0$ and $83.6 \%$, respectively. The specificity of this ELISA was 93.4, 92.9 and 93.1\%, respectively. ELISA using CPSs antigens could therefore serve as a valuable aid in serodiagnosis of Klebsiella pneumonia.
\end{abstract}

Keywords: Molecular Characterization, Immunoprotective Activity, Klebsiella Pneumoniae, Capsular Polysaccharide Corresponding Author: Ahmed M.A. Mansour, Department of Medical Laboratory, Faculty of Applied Medical Sciences, Taraba, Taif University, KSA 


\section{INTRODUCTION}

Klebsiella is an important opportunistic pathogen, which was reported worldwide. In human, it can causes infections of respiratory tract, nasal mucosa, pharynx and generally results in primary pneumonia. Klebsiella species were found to be the most frequently isolated gram negative bacteria in cases of primary bacteremia. It is the second pathogen, next to $E$. coli that causes urinary tract infection (Renuka et al., 2013). Klebsiella pneumoniae was isolated from milk and dry udder secretum of cattle and from the bedding of the cubicles. This represents a serious problem because of Klebsiella mastitis is severe and difficult to control. Also Klebsiellae are incriminated as the most frequent isolate of respiratory diseases in all species of domestic animals. Klebsiella pneumoniae is a facultative anaerobic, nonmotile, rod-shaped, gram-negative bacterium with a prominent polysaccharide capsule. This capsule encases the entire cell surface, accounts for the large appearance of the organism on gram stain and provides resistance against many host defense mechanisms. Members of the Klebsiella genus typically express 2 types of antigens on their cell surface. The first is a lipopolysaccharide $(\mathrm{O}$ antigen); the other is a capsular polysaccharide ( $\mathrm{K}$ antigen). Both of these antigens contribute to pathogenicity (Loschko et al., 2011). The structural variability of these antigens forms the basis for classification into various serotypes. The virulence of all serotypes appears to be similar. Capsule plays a very important role in virulence. Increasing emergence of multi-drug resistance among Klebsiella pneumoniae nosocomial isolates (Hotchkiss et al., 2013) has renewed interest in the investigation of alternative approaches to the treatment or prophylaxis of Klebsiella pneumoniae infections. The diagnosis of Klebsiella infection is made on the basis of clinical examination, isolation and identification of the organism. Laboratory identification is usually carried out by cultures, gram staining and a battery of biochemical tests. Bacterial isolation takes 24 $\mathrm{h}$ and biochemical tests have their own limitations in that the results may be available only after $48 \mathrm{~h}$. Even then accurate identification at species level of the genus may not be possible in all cases (Shon et al., 2013). Hence, the need arises for reliable and quick serological methods for rapid diagnosis of Klebsiella infections. Several serological assays for detection of antibody and antigen have been developed and these include capsular swelling reaction, ELISA and so on. The problems with most of the reported antibody and antigen detection assays so far have been the low reproducibility, sensitivity and specificity with high cost. The reason being, most of the antigenic moieties and polyclonal antibodies used are common to many related and unrelated bacterial species. As a result most of these assays have exhibited low potential in endemic areas due to ubiquitous nature of Klebsiella and shows extensive cross reactions among themselves (Hackstein et al., 2013). Since there is a need to develop more sensitive and specific assay.With this aspect in view, the present study was initiated with the following aims and objectives:

- To isolate and identify Klebsiella pneumoniae from faecal, nasopharyngeal and milk samples collected from diseased and apparently healthy farm animals to biotypes

- To determine the antibiotic profile of isolated Klebsiella pneumoniae subspecies

- To extract and characterize capsular polysaccharide antigen of Klebsiella pneumoniae subspecies

- To evaluate the immungenicity and protective capacity of capsular polysaccharide by ELISA, challenge test and histopathology investigations

- To develop rapid and simple antigen detection immunoassay with capsular polysaccharide for the diagnosis of Klebsiella pneumoniae subspecies infection

\section{MATERIALS AND METHODS}

Samples for isolation of Klebsiella Pneumoniae subspecies: A total of 465 samples were collected from various animal species (132 from cows, 113 from sheep, 111 from goats and 109 samples were obtained from camels).The samples included.

Faecal samples: A total of 92 faecal samples were collected from diarrhoeic; cows (28), sheep (22), goats (22) and camels (20) as well as 73 faecal samples were collected from apparently healthy cows (20), sheep (15), goats (20) and camels (18) Samples were taken from rectum under a separate polyethylene bag.

Nasopharyngeal swabs: A total of 89 nasopharyngeal swabs were collected from animals suffering from respiratory manifestation; cows (25), sheep (23), goats (21) and camels (20) while 69 ones were collected from apparently healthy, cows (19), sheep (18), goats (14) and camels (18). Nasopharyngeal swabs were collected from animals suffering from respiratory manifestations and apparently healthy animals by mean of sterile cotton swabs from the same animal species. 
Milk samples: A total of 83 milk samples were collected from clinically mastitic animals; cows (25), sheep (21), goats (19) and camels (18). As well as, 59 milk samples were aseptically collected from apparently healthy cows (15), sheep (14), goats (15) and camels (15). The milk was drawn by hand as aseptically as possible, the first four streams being discarded. The samples were collected in clean sterile screw-capped bottles of $30 \mathrm{~mL}$ capacity. Each sample represented one case was incubated at $37^{\circ} \mathrm{C}$ for $24 \mathrm{~h}$ before cultivation on solid media.

Samples for serodiagnosis: A total of 465 blood samples were collected from the same examined animals, then the sera were prepared and stored at $-20^{\circ} \mathrm{C}$.

\subsection{Isolation of Klebsiella Pneumoniae}

The isolation of Klebsiella pneumoniae subspecieswere done by cultivation of collected samples into Hekton enteric agar, Eosin methylene, blue agar, MacConkey's bile salt agar and Blood agar as described by Gundogan and Avci (2013).

\subsection{Identification of the Isolates}

The Identification of purified colonies was carried out mainly according to Chander et al. (2011) as indicated in Table 1.

\subsection{Susceptibility of Isolated Klebsiella pneumoniae Strains to Different Antimicrobial Agents}

Klebsiella pneumoniae subspecies strains isolated in the present study were subjected to susceptibility testing against 23 antimicrobials commonly used. Susceptibility was determined by the disk-diffusion technique of Kirby-Bauer on Mueller-Hinton agar plates (Oxoid Basingstoke, UK) with inocula adjusted to an optical density of 0.5 McFarland standard units. Disks containing ampicillin (AMP10 $\mu \mathrm{g}$ ), amoxicillin (AML10 $\mu \mathrm{g}$ ), amoxicillin/clavulanic acid (AMC30 $\mu \mathrm{g}$ ), pi $\neg$ peracillin (PRL100 $\mu \mathrm{g}$ ), ticarcillin (TIC75 $\mu \mathrm{g}$ ), ticarcillin/clavulanic acid (TIM85 $\mu \mathrm{g}$ ), cephalothin (KF30 $\mu \mathrm{g}$ ), cefoxitin (FOX30 $\mu \mathrm{g}$ ), cefotaxime (CTX30 $\mu \mathrm{g})$, cefoperazone $(\mathrm{CFP} 30 \mu \mathrm{g})$, ceftazidime (CAZ30 $\mu \mathrm{g})$, ceftriaxone (CRO30 $\mu \mathrm{g})$, cefepime (FEP30 $\mu \mathrm{g})$, aztreonam (ATM30 $\mu \mathrm{g}$ ), imipenem (IMP10 $\mu \mathrm{g}$ ), gentamicin (CN10 $\mu \mathrm{g})$, kanamycin (K30 $\mu \mathrm{g})$, tetracycline (TE30 $\mu \mathrm{g})$, ciprofloxacin (CIP5 $\mu \mathrm{g})$, norfloxacin (NOR10 $\mu \mathrm{g}$ ), erythromycin (E15 $\mu \mathrm{g}$ ), trimethoprim/sulfamethoxazole (SXT25 $\mu \mathrm{g}$ ) and chloramphenicol $(\mathrm{C} 30 \mu \mathrm{g})$ were used. All disks were obtained from Oxoid. After $24 \mathrm{~h}$ incubation at $30^{\circ} \mathrm{C}$, organisms were classified as Sensitive (S), Intermediately resistant (I) or Resistant (R) on the basis of the size of the zone of bacteria growth inhibition according to the guidelines of the (Chika et al., 2013).

\subsection{Extraction and Purification of Capsular Polysaccharides}

Klebsiella pneumoniae CPSs were extracted and purified according to method of Sikarwar and Batra (2011). Briefly: Bacteria were grown on trypticase soy broth at $370 \mathrm{C}$ withshaking at $100 \mathrm{rpm}$ in a shaker incubator for $16 \mathrm{~h}$. Organisms were harvested by centrifugation at $10,000 \times \mathrm{g}$ for $30 \mathrm{~min}$. Cetavlon, was added to a final concentration of $0.5 \%$. After stirring for $30 \mathrm{~min}$ at roomtemperature, the precipitate was collected bycentrifugation. The material was dissolved in $1 \mathrm{M} \mathrm{CaCl} 2$ solution and $25 \%$ ethanol was added to it in equal amount. After stirring for $60 \mathrm{~min}$ at room temperature, theprecipitated nucleic acid were removed by centrifugation at $10,000 \times \mathrm{g}$ for $30 \mathrm{~min}$. The CPS was precipitated fromthe resultant supernatant by addition of equal volume of $80 \%$ ethanol. The CPS was dissolved in distilled water andextracted three times with an equal volume of chloroform-butanol solution (5:1). The pooled water phases wereextensively dialyzed against distilled water at $40 \mathrm{C}$ and thenvacuum concentrated. Finally the solution was centrifugedat $100,000 \times \mathrm{g}$ for $16 \mathrm{~h}$ for the removal oflipopolyssacharide. The resulting pellet was discarded andsupernatant containing CPS was collected.

\subsection{Polyacrylamide Gel Electrophoresis}

PAGE was carried for molecular characterization of capsular polysaccharide and the gel was then subjected to alcian blue silver staining under normal light using the method developed by Yi-Jiun et al. (2013).

\subsection{Mice Immunization}

For animal immunization, groups of 20 mice were immunized intramuscularly with $1 \mu \mathrm{g}$ of each CPSs of Klebsiella pneumoniae in $100 \mu \mathrm{L}$ of PBS on day 0 and 14. Control mice groups were inoculated with PBS alone. Blood samples were collected one and two weeks after 1st dose of immunization and one and two weeks after 2 nd dose of immunization. Blood samples were also collected from control mice; the serum was separated and stored at $20^{\circ} \mathrm{C}$ for serological examination using ELISA test. 
Table 1. Differentiation of Klebsiella species by biochemical tests Klebsiella pneumoniae subspecies

\begin{tabular}{|c|c|c|c|c|c|c|c|}
\hline \multirow[b]{2}{*}{ Test } & & \multirow[b]{2}{*}{ K. oxytoca } & \multirow[b]{2}{*}{ K. ornithinolytica } & \multirow[b]{2}{*}{ K. planticola } & \multirow[b]{2}{*}{ K. terrigena } \\
\hline & Pneumonia & Ozaenae & Rhiboscleromatis & & & & \\
\hline Ndole & - & - & - & + & + & $\mathrm{v}(20)$ & - \\
\hline Methyl red & - & + & + & $\mathrm{v}(20)$ & + & + & $\mathrm{v}(60)$ \\
\hline Voges Proskauer & + & - & - & + & $\mathrm{v}(70)$ & + & + \\
\hline Simmons citrate & + & $\mathrm{v}(30)$ & - & + & + & + & $\mathrm{v}(40)$ \\
\hline Hydrogen sulfide & - & - & - & - & - & - & - \\
\hline Urease & + & - & - & + & + & + & - \\
\hline Gelatin liquefaction at $22^{\circ} \mathrm{C}$ & - & - & - & - & - & - & - \\
\hline D-glucose acid production & + & + & + & + & + & + & + \\
\hline D-glucose gas production & + & $\mathrm{v}(50)$ & - & + & + & + & $\mathrm{v}(80)$ \\
\hline Lactose & + & $\mathrm{v}(30)$ & - & + & + & + & + \\
\hline Sucrose & + & $\mathrm{v}(20)$ & $\mathrm{v}(57)$ & + & + & + & + \\
\hline D-mannitol & + & + & + & + & + & + & + \\
\hline Dulcitol & $\mathrm{V}(30)$ & - & - & $\mathrm{v}(55)$ & - & $\mathrm{v}(15)$ & $\mathrm{v}(20)$ \\
\hline Salicin & + & + & + & + & + & + & + \\
\hline Malonate & + & - & + & + & + & + & + \\
\hline$\beta$-gentiobiose & + & + & - & + & + & + & + \\
\hline D-glucosamine & + & - & + & + & - & + & + \\
\hline Mesotartrate & - & - & + & + & + & + & + \\
\hline D-turanose & - & + & - & - & + & + & + \\
\hline D-adonitol & + & + & + & + & + & + & + \\
\hline Inositol & + & $\mathrm{v}(55)$ & + & + & + & + & $\mathrm{v}(80)$ \\
\hline D-sorbitol & + & $\mathrm{v}(65)$ & + & + & + & + & + \\
\hline L-arabinose & + & + & + & + & + & + & + \\
\hline Raffinose & + & + & + & + & + & + & + \\
\hline L-rhamnose & + & $\mathrm{v}(55)$ & + & + & + & + & + \\
\hline Maltose & + & + & + & + & + & + & + \\
\hline Trehalose & + & + & + & + & + & + & + \\
\hline
\end{tabular}

(+): Most strains positive (-): Most strains negative (V): Some strains positive, others negative

\subsection{Enzyme Linked Immunosorbent Assay}

Enzyme linked immunosorbent assay for detection of anti-capsular polysaccharide antibodies was performed as recorded by Zahran and Abdeen (2013).

\subsection{Determination of Protection Using Challenge Test}

Challenge of mice: All groups of control and immunized mice were challenged 2 weeks after booster dose of immunization I/P with $1 \mathrm{~mL}$ of 100 LD50 of homologous and heterologous strains (Isolated from diseased animals) of Klebsiella pneumoniae subspecies (Liu et al., 2013).

Mice were clinically observed for 4 weeks after challenge. Different organs (lung, liver and spleen) were collected from died mice for reisolation of Klebsiella pneumoniae and for histopatholgical examination.

\subsection{Reisolation and Identification of Klebsiella pneumoniae after Challenge}

Samples from mice internal organs (lung, spleen and liver) were taken from dead immunized and control mice at 4 weeks post challenge. The samples were transferred to test tube contains peptone water. The inoculated tubes were incubated at $37^{\circ} \mathrm{C}$ for $24 \mathrm{~h}$. Then subculture were made on MacConky's agar for further $24 \mathrm{~h}$ at $37^{\circ} \mathrm{C}$ suspected colonies were picked up for further identificationas described before.

\subsection{Histopathological Studies}

Samples of lung, spleen and liver were taken for histopathological examination. Tissues were fixed in $10 \%$ buffered neutral formalin, cut at $6 \mu \mathrm{m}$ and stained with haematoxylin and eosin stain. The sections were examined microscopically (Joshi et al., 2012). 
Mortality rates: Mortality rates were recorded in all groups during experimental period.

\subsection{Serodiagnosis of Klebsiella pneumoniae Subspeciesin Examined Farm Animals}

Serum collected from cows, sheep, goats and camels were subjected to ELISA to detect anticapsular polysaccharide antibodies in examined animals (Zahran and Abdeen, 2013).

The sensitivity and specificity were calculated according to the following formula.

$$
\begin{aligned}
& \text { Sensitivity }=\frac{\text { True positive }}{\text { True positive }+ \text { False negative }} \\
& \text { Sepecificity }=\frac{\text { True negative }}{\text { True negative }+ \text { False positive }}
\end{aligned}
$$

\section{RESULTS}

Bacteriological examination of a total of (246) samples obtained from diseased different animal species showed that 62 cases (25.2\%) harboured Klebsiella pneumoniae. Moreover, it was found that there was great difference between the prevalence of Klebsiella isolated from various animal origins, as it was higher in cows, followed by sheep, goats and lastly camels with percentages of $25.6,24.2,21.2$ and $20.7 \%$, respectively (Table 2). The biochemical testing of 62 isolates of Klebsiella pneumoniae revealed their identification into Klebsiella pneumoniae subsp. pneumoniae 44 (17.9\%), Klebsiella pneumoniae subsp. Ozaenae 14 (5.7\%) and Klebsiella pneumoniae subsp. rhinoscleromatis 4 (1.6\%), from 246 samples obtained from diseased animals. In Table 2, regarding to the distribution and frequency of occurrence of Klebsiella pneumoniae subspecies isolated from diseased cows in relation to its sites of isolation, it can be concluded that the incidence of Klebsiella pneumoniae subspeciesin faecal samples (32.1\%) followed by nasopharyngeal swabs $(28.7 \%)$, the lowest incidence could be isolated from milk samples (16.0\%). In sheep, Klebsiella pneumoniae subspecies incidence recovered from faecal samples $(40.9 \%)$, nasopharyngeal swabs (17.4\%) and milk samples (14.3\%). In goats, Klebsiella pneumoniae subspecies were isolated from faecal samples, nasopharyngeal swabs and milk samples in an incidence of (31.8\%), (26.3\%) and (19.0\%) respectively. In camel, Klebsiella pneumoniae subspecies incidence recovered from faecal samples (40.0\%), nasopharyngeal swabs $(15.0 \%)$ and milk samples (5.6\%). Results illustrated in Table 3, revealed that bacteriological examination of a total of 201 samples obtained from apparently healthy animal species showed that 11 cases $(5.5 \%)$ harboured Klebsiella pneumoniae. Table 2 shows the distribution of Klebsiella pneumoniae subspecies among different animals It is clear that there was great difference between the prevalence of Klebsiella isolated from various animal origins, as it was higher in sheep, followed by cow, goats and lastly camels with percentages of $8.5,5.5,4.1$ and $3.9 \%$, respectively. The biochemical testing of 11 isolates of Klebsiella pneumoniae revealed their identification into Klebsiella pneumoniae subsp. pneumoniae (8) and Klebsiella pneumoniae subsp. ozaenae (3). On the other hand, it is of interest to notice that, Klebsiella pneumoniae subsp. rhinoscleromatis was not isolated from apparently healthy animals. The in vitro sensitivity of 52 Klebsiella pneumoniae subsp. pneumoniae, 17 Klebsiella pneumoniae subsp. ozaenae and 4Klebsiella pneumoniae subsp. rhinoscleromatis isolates recovered from different animal species to 23 antimicrobial agents was determined. The results are presented in Table 4 (in percentage) it is evident that all Klebsiella pneumoniae subsp isolates were resistance to $\beta$-lactams antibiotics as cefoxitin, cefotaxime, cefoperazone, ceftazidime, ceftriaxone and aztreonam Moreover, all isolated strains were resistance to amoxicillin and ampicillin. The most potent antibiotics showing $100 \%$ activity against Klebsiella pneumoniae subsp. Isolated in this study were imipenem, ciprofloxacin, norfloxacin, gentamicin and kanamycin. While $96.2 \%$ of all examined isolates were sensitive to amoxicillin/clavulanic acid and ticarcillin/clavulanic acid. Results obtained in Fig. 1, revealed that when CPSs of Klebsiella pneumoniae isolated from different animals species were separated by polyacrylamide gel electrophoresis, they gave about 10 to 13 bands ranged in their molecular weights from $15.52 \mathrm{kDa}$ to $106.29 \mathrm{kDa}$. For evaluation of humoral immune response of mice immunized with CPSs, the ELISA was conducted and the absorbance values were detected.As it could be seen from Table 5, the absorbance values were increased 7 days post first immunization and reached to $0.280 \pm 0.006,0.395 \pm 0.009$ and $0.313 \pm 0.031$ in mice immunized with CPSs extracted from Klebsiella pneumoniae subsp. Pneumoniae, Klebsiella pneumoniae subsp. ozaenae and Klebsiella pneumoniae subsp. rhinoscleromatis, respectively. The highest absorbance values were obtained 14 days after 1 st dose of immunization with the three extracted CPSs. From data presented in Table 6, it is evident that on challenging the mice immunized with CPSs Klebsiella pneumoniae subsp. pneumoniae with Klebsiella pneumoniae subsp. 
Ahmed M.A. Mansour et al. / American Journal of Infectious Diseases 10 (1): 1-14, 2014

Table 2. Incidence of Klebsiella pneumonia subspecies in diseased animals as regards to variation of the sites of isolation

\begin{tabular}{|c|c|c|c|c|c|c|c|c|c|c|c|c|c|}
\hline \multirow[b]{2}{*}{$\begin{array}{l}\text { Klebsiella pneumonia } \\
\text { subspecies }\end{array}$} & \multicolumn{3}{|c|}{ Cows (78) } & \multicolumn{3}{|c|}{ Sheep (66) } & \multicolumn{3}{|c|}{ Goats (62) } & \multicolumn{3}{|c|}{ Camels (58) } & \multirow[b]{2}{*}{$\begin{array}{l}\text { No of } \\
\text { olates }\end{array}$} \\
\hline & $\begin{array}{l}\text { F.S } \\
(28 \%)\end{array}$ & $\begin{array}{l}\text { N.S } \\
(25 \%)\end{array}$ & $\begin{array}{l}\text { M.S } \\
(25 \%)\end{array}$ & $\begin{array}{l}\text { F.S } \\
(22 \%)\end{array}$ & $\begin{array}{l}\text { N.S } \\
(23 \%) \\
\end{array}$ & $\begin{array}{l}\text { M.S } \\
(21 \%)\end{array}$ & $\begin{array}{l}\text { F.S } \\
(22 \%)\end{array}$ & $\begin{array}{l}\text { N.S } \\
(21 \%)\end{array}$ & $\begin{array}{l}\text { M.S } \\
(19 \%)\end{array}$ & $\begin{array}{l}\text { F.S } \\
(20 \%)\end{array}$ & $\begin{array}{l}\text { N.S } \\
(20 \%)\end{array}$ & $\begin{array}{l}\text { M.S } \\
(218 \%)\end{array}$ & \\
\hline $\begin{array}{l}\text { K. pneumonia } \\
\text { subsp. Pneumonia }\end{array}$ & 621.4 & 416.0 & 312.0 & 522.7 & 417.4 & 14.8 & 522.7 & 314.3 & 315.8 & 630.0 & 315.0 & 15.6 & 4417.9 \\
\hline $\begin{array}{l}\text { K. pneumonia } \\
\text { subsp. ozaenae. }\end{array}$ & 27.1 & 28 & 14.0 & 313.6 & 00.0 & 29.5 & 14.5 & 14.8 & 00.0 & 210.0 & 00.0 & 00.0 & 145.7 \\
\hline $\begin{array}{l}\text { K.pneumoniae subsp } \\
\text { Rhinoscleromatis }\end{array}$ & 13.6 & 14.0 & 00.0 & 14.5 & 00.0 & 00.0 & 14.5 & 00.0 & 00.0 & 00.0 & 00.0 & 00.0 & 41.6 \\
\hline Total & $\begin{array}{l}932.1 \\
2025.6 \%\end{array}$ & 728.0 & 416.0 & $\begin{array}{l}940.9 \\
1624.2 \%\end{array}$ & 417.4 & 314.3 & $\begin{array}{l}731.8 \\
1421.2 \\
\end{array}$ & $\begin{array}{l}419.0 \\
\%\end{array}$ & 326.3 & $\begin{array}{l}840.0 \\
1220.7 \\
\end{array}$ & 315.0 & 15.6 & 6225.2 \\
\hline
\end{tabular}

Table 3. Incidence of different Klebsiella pneumoniae subspecies in apparently healthy animals as regards to variation of the sites of isolation

\begin{tabular}{|c|c|c|c|c|c|c|c|c|c|c|c|c|c|}
\hline \multirow[b]{2}{*}{$\begin{array}{l}\text { Klebsiella pneumonia } \\
\text { subsp }\end{array}$} & \multicolumn{3}{|c|}{ Cows (54) } & \multicolumn{3}{|c|}{ Sheep (47) } & \multicolumn{3}{|c|}{ Goats (49) } & \multicolumn{4}{|c|}{ Camels (51) } \\
\hline & $\begin{array}{l}\text { F.S } \\
(20 \%)\end{array}$ & $\begin{array}{l}\text { N.S } \\
(19 \%)\end{array}$ & $\begin{array}{l}\text { M.S } \\
(15 \%)\end{array}$ & $\begin{array}{l}\text { F.S } \\
(15 \%)\end{array}$ & $\begin{array}{l}\text { N.S } \\
(18 \%)\end{array}$ & $\begin{array}{l}\text { M.S } \\
(14 \%)\end{array}$ & $\begin{array}{l}\text { F.S } \\
(20 \%)\end{array}$ & $\begin{array}{l}\text { N.S } \\
(14 \%)\end{array}$ & $\begin{array}{l}\text { M.S } \\
(15 \%)\end{array}$ & $\begin{array}{l}\text { F.S } \\
(18 \%)\end{array}$ & $\begin{array}{l}\text { N.S } \\
(18 \%)\end{array}$ & $\begin{array}{l}\text { M.S } \\
(15 \%)\end{array}$ & $\begin{array}{l}\text { No of } \\
\text { olates }\end{array}$ \\
\hline $\begin{array}{l}\text { K. pneumonia } \\
\text { subsp. Pneumonia }\end{array}$ & 0.00 & 15.3 & 16.7 & 16.70 & 211.10 & 00.0 & 15.0 & 00.0 & 00.0 & 15.5 & 15.5 & 00.0 & 84.0 \\
\hline $\begin{array}{l}\text { K. pneumonia } \\
\text { subsp. Ozaenae }\end{array}$ & 15.0 & 00.0 & 00.0 & 16.70 & 00.00 & 00.0 & 15.0 & 00.0 & 00.0 & 00.0 & 00.0 & 00.0 & 31.5 \\
\hline $\begin{array}{l}\text { K.pneumoniae subsp } \\
\text { Rhinoscleromatis }\end{array}$ & 00.0 & 00.0 & 00.0 & 00.00 & 00.00 & 00.0 & 00.0 & 00.0 & 00.0 & 00.0 & 00.0 & 00.0 & 00.0 \\
\hline Total & $\begin{array}{l}15.0 \\
35.5 \%\end{array}$ & 15.3 & 16.7 & $\begin{array}{l}213.3 \\
48.5 \%\end{array}$ & 211.10 & 010.0 & $\begin{array}{l}20.0 \\
24.1 \%\end{array}$ & 00.0 & 00.0 & $\begin{array}{l}15.5 \\
23.9 \%\end{array}$ & 15.5 & 00.0 & 115.5 \\
\hline
\end{tabular}

Table 4. Variations in susceptibilities (\%) among different Klebsiella pneumoniae subspecies isolates recovered from different animal species (using disk diffusion method)

\begin{tabular}{|c|c|c|c|c|c|c|c|c|}
\hline \multirow[b]{2}{*}{ Antibiotics used } & \multicolumn{2}{|c|}{$\begin{array}{l}\text { K. pneumoniae subsp } \\
\text { Pneumoni (52) }\end{array}$} & \multicolumn{2}{|c|}{$\begin{array}{l}\text { K. pneumoniae } \\
\text { subsp. ozaenae (17) }\end{array}$} & \multicolumn{2}{|c|}{$\begin{array}{l}\text { K. pneumoniae. } \\
\text { subsp. (4) }\end{array}$} & \multicolumn{2}{|c|}{$\begin{array}{l}\text { Total } \\
(73)\end{array}$} \\
\hline & No. & $(\%)$ & No. & $(\%)$ & No. & $(\%)$ & No. & $(\%)$ \\
\hline AMP & 0 & 0.00 & 0 & 0.00 & 0 & 0 & 0 & 0.00 \\
\hline AML & 0 & 0.00 & 0 & 0.00 & 0 & 0 & 0 & 0.00 \\
\hline AMC & 50 & 96.20 & 17 & 100.00 & 4 & 100 & 70 & 95.90 \\
\hline TIC & 6 & 11.50 & 0 & 0.00 & 0 & 0 & 6 & 8.20 \\
\hline TIM & 50 & 96.20 & 17 & 100.00 & 3 & 75 & 70 & 95.90 \\
\hline PRL & 0 & 0.00 & 0 & 0.00 & 0 & 0 & 0 & 0.00 \\
\hline KF & 28 & 53.80 & 4 & 23.50 & 1 & 25 & 33 & 45.20 \\
\hline FOX & 0 & 0.00 & 0 & 0.00 & 0 & 0 & 0 & 0.00 \\
\hline CRO & 0 & 0.00 & 0 & 0.00 & 0 & 0 & 0 & 0.00 \\
\hline CAZ & 0 & 0.00 & 0 & 0.00 & 0 & 0 & 0 & 0.00 \\
\hline CFP & 0 & 0.00 & 0 & 0.00 & 0 & 0 & 0 & 0.00 \\
\hline CTX & 0 & 0.00 & 0 & 0.00 & 0 & 0 & 0 & 0.00 \\
\hline FEP & 1 & 1.90 & 0 & 0.00 & 0 & 0 & 1 & 1.40 \\
\hline ATM & 0 & 0.00 & 0 & 0.00 & 0 & 0 & 0 & 0.00 \\
\hline IMP & 100 & 100.00 & 17 & 100.00 & 4 & 100 & 73 & 100.00 \\
\hline CIP & 100 & 100.00 & 17 & 100.00 & 4 & 100 & 73 & 100.00 \\
\hline NOR & 100 & 100.00 & 17 & 100.00 & 4 & 100 & 73 & 100.00 \\
\hline K & 100 & 100.00 & 17 & 100.00 & 4 & 100 & 73 & 100.00 \\
\hline $\mathrm{CN}$ & 100 & 100.00 & 17 & 100.00 & 4 & 100 & 73 & 100.00 \\
\hline TE & 0 & 0.00 & 0 & 0.00 & 0 & 0 & 0 & 0.00 \\
\hline $\mathrm{C}$ & 3 & 5.80 & 0 & 0.00 & 0 & 0 & 3 & 4.10 \\
\hline E & 0 & 0.00 & 0 & 0.00 & 0 & 0 & 0 & 0.00 \\
\hline SXT & 5 & 9.60 & 1 & 5.90 & 0 & 0 & 6 & 8.20 \\
\hline
\end{tabular}


Ahmed M.A. Mansour et al. / American Journal of Infectious Diseases 10 (1): 1-14, 2014

Table 5. Humoral immune response of mice immunized with CPSs extracted from Klebsiella pneumoniae subspecies

\begin{tabular}{|c|c|c|c|c|}
\hline \multirow[b]{2}{*}{ Time of sampling } & \multicolumn{3}{|l|}{ CPSs extracted from } & \multirow[b]{2}{*}{ Control } \\
\hline & $\begin{array}{l}\text { K.pneumoniae subsp. } \\
\text { pneumoniae }\end{array}$ & $\begin{array}{l}\text { K. pneumoniae subsp. } \\
\text { ozaenae }\end{array}$ & $\begin{array}{l}K . \text { pneumonia subs- } \\
\text { prhinoscleromatis }\end{array}$ & \\
\hline Preimmuinization & $0.102 \pm 0.001 *$ & $0.062 \pm 0.005$ & $0.081 \pm 0.004$ & $0.099 \pm 0.007$ \\
\hline 1st immuinization (1 WPI) & $0.280 \pm 0.006$ & $0.395 \pm 0.009$ & $0.313 \pm 0.031$ & $0.121 \pm 0.003$ \\
\hline$(2 \mathrm{WPI})$ & $0.891 \pm 0.018$ & $0.921 \pm 0.013$ & $0.982 \pm 0.011$ & $0.103 \pm 0.009$ \\
\hline 2nd immuinization (1WPI) & $0.783 \pm 0.009$ & $0.831 \pm 0.021$ & $0.857 \pm 0.015$ & $0.094 \pm 0.009$ \\
\hline$(2 \mathrm{WPI})$ & $0.882 \pm 0.010$ & $0.811 \pm 0.018$ & $0.893 \pm 0.021$ & $0.101 \pm 0.010$ \\
\hline
\end{tabular}

* = Mean Optical density \pm Standard deviation WPI $=$ WeakpostimmunizationOptical density value $\geq 0.2$ consider positive

Table 6. Mortality rate and reisolation of Klebsiella pneumoniae subspecies from mice organs 4 weeks post challenge

\begin{tabular}{|c|c|c|c|c|c|c|c|c|c|}
\hline \multirow{3}{*}{$\begin{array}{l}\text { Mice immunized by } \\
\text { CPSs extracted from }\end{array}$} & \multirow{3}{*}{$\begin{array}{l}\text { Challenge } \\
\text { organism }\end{array}$} & \multirow{3}{*}{$\begin{array}{l}\text { No. of } \\
\text { dead }\end{array}$} & \multirow{3}{*}{$\begin{array}{l}\text { Mortality } \\
\text { rate }(\%)\end{array}$} & \multicolumn{6}{|c|}{ Reisolation from } \\
\hline & & & & Lung & & Liver & & Spleen & \\
\hline & & & & No. & $(\%)$ & No. & $(\%)$ & No. & $(\%)$ \\
\hline \multirow{3}{*}{$\begin{array}{l}\text { Klebsiella pneumoniae } \\
\text { subsp. pneumoniae }\end{array}$} & K.P.P. & $1 / 20$ & 5 & $1^{*}$ & 5 & 0 & 0 & 1 & 5 \\
\hline & K.P.oz. & $2 / 20$ & 10 & 2 & 10 & 1 & 5 & 2 & 10 \\
\hline & K.P.rh. & $2 / 20$ & 10 & 2 & 10 & 1 & 5 & 2 & 10 \\
\hline \multirow{3}{*}{$\begin{array}{l}\text { Klebsiella pneumoniae } \\
\text { subsp. ozaenae }\end{array}$} & K.P.P. & $2 / 20$ & 10 & 2 & 10 & 1 & 5 & 2 & 10 \\
\hline & K.P.oz. & $1 / 20$ & 5 & 0 & 0 & 0 & 0 & 1 & 5 \\
\hline & K.P.rh. & $2 / 20$ & 10 & 2 & 10 & 1 & 5 & 2 & 10 \\
\hline \multirow{3}{*}{$\begin{array}{l}\text { Klebsiella pneumoniae } \\
\text { subsp. rhinoscleromatis }\end{array}$} & K.P.P. & $3 / 20$ & 15 & 2 & 10 & 1 & 5 & 3 & 15 \\
\hline & K.P.oz. & $2 / 20$ & 10 & 2 & 10 & 2 & 10 & 2 & 10 \\
\hline & K.P.rh. & $2 / 20$ & 10 & 1 & 5 & 1 & 5 & 2 & 10 \\
\hline \multirow[t]{3}{*}{ Control (non-immunized) } & K.P.P. & $15 / 20$ & 75 & 11 & 55 & 11 & 55 & 15 & 75 \\
\hline & K.P.oz. & $16 / 20$ & 80 & 12 & 60 & 12 & 60 & 16 & 80 \\
\hline & K.P.rh. & $13 / 20$ & 65 & 10 & 50 & 10 & 50 & 13 & 65 \\
\hline
\end{tabular}

K.P.P. $=$ K. pneumoniae subsp. Pneumonia, K.P. oz $=$ K.pneumoniae subsp.ozaenae K. P. rh. $=$ K.pneumoniae subsp. rhinoscleromatis $*$ No. of culture positive percent calculated according to no. of culture positive to total number of each challenged group

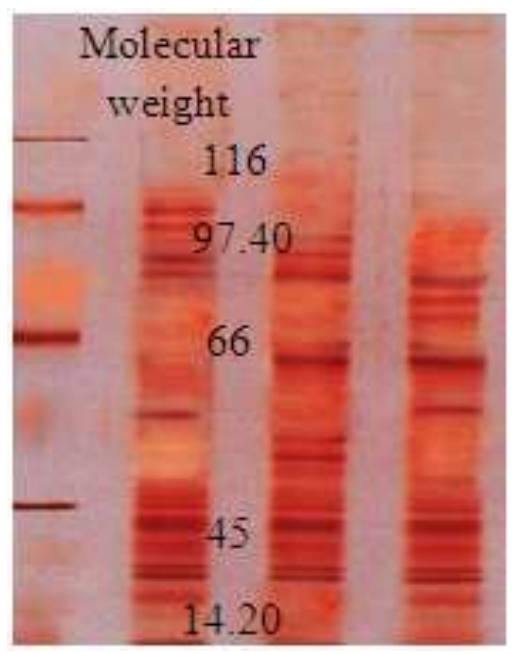

Fig. 1. Analysis of CPSs of three strains of Klebsiella pneumoniae subspecies Lane (1) Marker Lane (2) CPSs of $K$. pneumoniae subsp. pneumoniae. Lane (3) CPSs of $K$. pneumoniae subsp. ozaenae. Lane (4) CPSs of K. pneumoniae subsp. Rhinoscleromatis
Pneumoniae, $5 \%$ of mice contracted the disease and died while, $10 \%$ of immunized mice with CPSs Klebsiella pneumoniae subsp. Pneumoniae and challenged with Klebsiella pneumoniae subsp. Ozaenae and Klebsiella pneumoniae subsp. rhinoscleromatis contracted the disease and died. As well as $10 \%$ of mice immunized with CPSs Klebsiella pneumoniae subsp. Ozaenae challenged with Klebsiella pneumoniae subsp. Pneumoniae and Klebsiella pneumoniae subsp. rhinoscleromatis died (heterologous) while, 5\% only died from mice challenged with Klebsiella pneumoniae subsp. Ozaenae (homologous). In case of mice immunized with CPSs Klebsiella pneumoniae subsp. rhinoscleromatis 15 and $10 \%$ died when challenged with heterologous strains of Klebsiella pneumoniae subsp. pneumoniae and Klebsiella pneumoniae subsp. Ozaenae, respectively while $10 \%$ died when challenging with homologous strain of Klebsiella pneumoniae subsp. Rhinoscleromais. Meanwhile 80,75 and $65 \%$ of the control non-immunized mice contracted the disease and 
died from Klebsiella pneumoniae subsp. pneumoniae, Klebsiella pneumoniae subsp. ozaenae and Klebsiella pneumoniae subsp. rhinoscleromatis, respectively. In group of mice immunized with CPSs of Klebsiella pneumoniae subsp. pneumoniae, the reisolation rates from lungs, liver and spleen were 5, 0 and $5 \%$ in mice challenged with homologous strain while 10,5 and $10 \%$ respectivelyin mice challenged with heterologous strains. In group of mice immunized with Klebsiella pneumoniae subsp. ozaenae, in homologous challenge the organism was isolated from spleen only in rate of $5 \%$. In heterologous challenge, the isolation from each lung and spleen was 10 while $5 \%$ from liver.Regarding to group of mice immunized with Klebsiella pneumoniae subsp. rhinoscleromatis, the isolation rate from each lung and liver was 5 and $10 \%$ from spleen on homologous challenge, while in heterologous challenge with Klebsiella pneumoniae subsp. pneumoniae the isolation rates were 10, 5 and $15 \%$ from lung, liver and spleen, respectively. Whereas in heterogonous challenge with Klebsiella pneumoniae subsp. ozaenae, the isolation rate was $10 \%$ from all examined organs. Concerning the control non-immunized mice challenged with Klebsiella pneumoniae subsp. pneumoniae, the isolation rates from lung and liver were $55 \%$ of each, while $75 \%$ from spleen. Whereas the isolation rates from mice challenged with Klebsiella pneumoniae subsp. ozaenae, were $60 \%$ from lung and liver and $80 \%$ from spleen. The isolation rates in mice challenged with Klebsiella pneumoniae subsp. rhinoscleromatis from lung, liver and spleen were 50, 50 and $65 \%$, respectively.

\subsection{Histopathological Findings}

Gross examination of the lungs of dead infected non-immunized mice showed involvement of one or more lobes, often affecting the entire lobe in a typical lobar distribution. The involvement was characteristically massive and voluminous, dull grayish regions, which released copious amounts of exudates upon sectioning with marked swelling of the lung. No other organs showed marked gross changes. Microscopic examination of the lungs of dead infected non-immunized mice revealed lobar pneumonia where the alveoli, peribronchial areas and the perivascular areas infiltrated with granulocytes and macrophages; accompanied by marked septal, perivascular edema and perivasculitis. Areas of necrosis could be found (Fig. 2 and 3). Microscopic examination of spleen appeared with hypoplasia and proliferation of reticuloendothelial cells (Fig. 4). Lesion in liver changed from congestion, vaculation of the hepatic cells to necrosis and atrophy where the hepatic cord appeared with disorganization and the nucleus revealed different stages of necrosis (Fig. 5). Regarding to macroscopic examination of the immunized mice, most of the lesion became mild and organs appeared to be normal. While microscopic examination of Lung of immunized infected mice showed mild pneumonia (Fig. 6), while spleen showed mild hypoplasia of white pulp (Fig. 7). Moreover, liver showed slight congestion of the central vein and hepatic cells appeared with normal arrangement (Fig. 8). ELISA has been used for detection of Klebsiella pneumoniae antibodies in farm animals as shown in Table 7. From the results illustrated in Table 7 it is clear that the sensitivity of ELISA using CPSs extracted from Klebsiella pneumoniae subsp. pneumoniae, Klebsiella pneumoniae subsp. ozaenae and Klebsiella pneumoniae subsp. rhinoscleromatis was $87.7,89.0$ and $83.6 \%$, respectively. The specificity of this ELISA was 93.4, 92 and $93.1 \%$, respectively.

Table 7. Detection of CPSs of Klebsiella pneumoniae subspecies antibodies in the serum of examined animals regarding to culture status

ELISA test using CPSs extracted from

\begin{tabular}{|c|c|c|c|c|c|c|c|c|c|c|c|c|}
\hline \multirow{3}{*}{$\begin{array}{l}\text { Culture status } \\
\text { positive for }\end{array}$} & \multirow[b]{3}{*}{ No } & & \multirow{3}{*}{$\begin{array}{l}\text { Sensit } \\
\text { ivity }\end{array}$} & \multirow{3}{*}{$\begin{array}{l}\text { Speci } \\
\text { ficity }\end{array}$} \\
\hline & & \multicolumn{3}{|c|}{$\begin{array}{l}\text { K. pneumoniae subsp. } \\
\text { Pneumoniae }\end{array}$} & \multicolumn{3}{|c|}{$\begin{array}{l}\text { K. pneumoniae subsp. } \\
\text { ozaenae }\end{array}$} & \multicolumn{3}{|c|}{$\begin{array}{l}\text { K. pneumoniae subsp. } \\
\text { rhinoscleromatis }\end{array}$} & & \\
\hline & & No. & $(\%)$ & Optical density & No & $(\%)$ & Optical density 1 & No. & $(\%)$ & Optical density & & \\
\hline K.pneumoniae subsp. & 52 & $47 *$ & 90.4 & $0.811 \pm 0.018$ & 46 & 88.5 & $0.798 \pm 0.012$ & 46 & 88.5 & $0.903 \pm 0.008$ & 87.7 & 93.4 \\
\hline Klebsiella pneumoniae & 17 & 14 & 82.4 & $0.857 \pm 0.015$ & 16 & 94.1 & $0.782 \pm 0.020$ & 11 & 46.7 & $0.834 \pm 0.019$ & 89.0 & 92.9 \\
\hline Klebsiella pneumoniae & 4 & 3 & 75.0 & $0.796 \pm 0.019$ & 3 & 75.0 & $0.807 \pm 0.015$ & 4 & 100.0 & $0.925 \pm 0.019$ & 83.6 & 93.1 \\
\hline Total positive & 73 & 64 & 87.7 & $0.745 \pm 0.019$ & 65 & 89.0 & $0.699 \pm 0.009$ & 61 & 83.6 & $0.846 \pm 0.015$ & & \\
\hline Total negative & 392 & 26 & 6.8 & $0.501 \pm 0.019$ & 28 & 7.1 & $0.609 \pm 0.020$ & 27 & 6.9 & $0.544 \pm 0.018$ & & \\
\hline
\end{tabular}




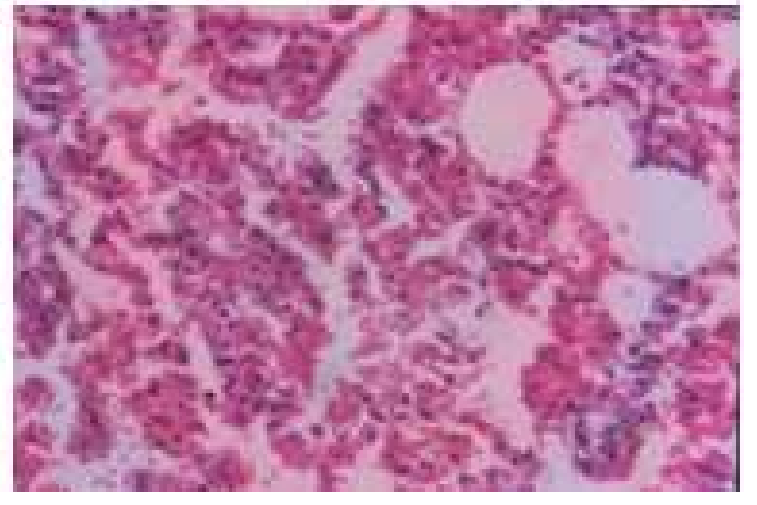

Fig. 2. Lung showed pneumonia where most of the alveoli filled with RBCs and infiltrated by mononuclear cells and macrophages in non-immunized challenged mice (Stain H\&E X100)

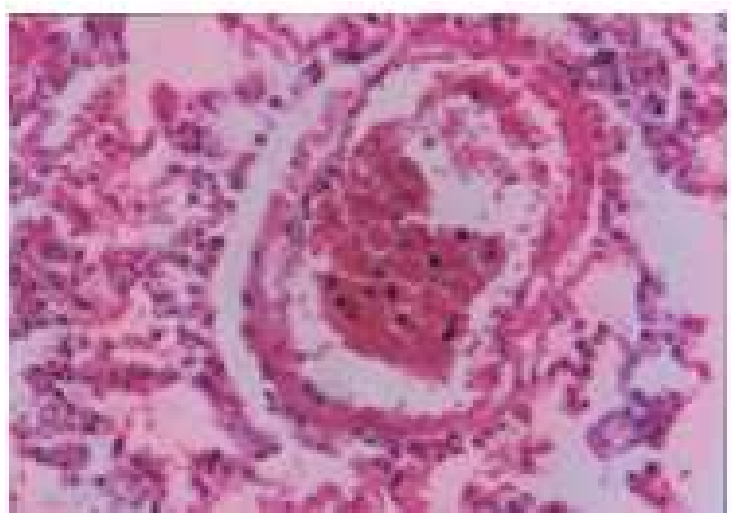

Fig. 3. Lung showed pneumonia and dilated blood vessels with perivascular edema and vesculitis in non-immunized challenged mice. (Stain H\&E X100)

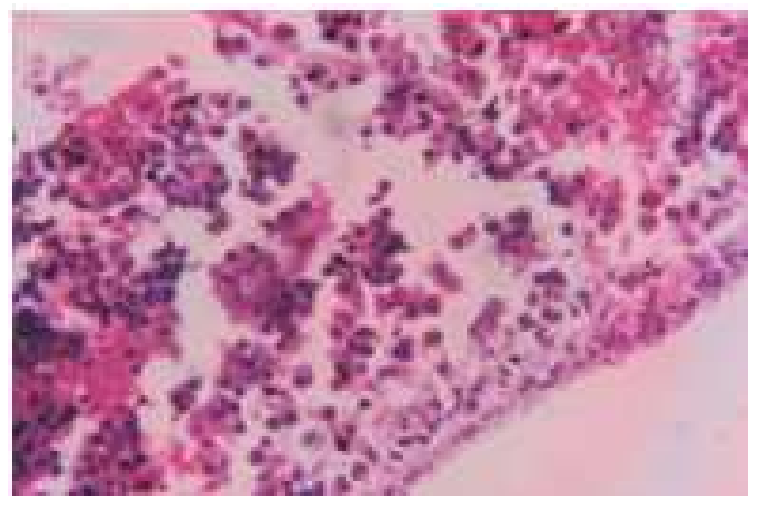

Fig. 4. Spleen showed hypoplasia of white pulb with reticuloendothelial cell proliferation in non-immunized challenged mice. (Stain H\&E X100)

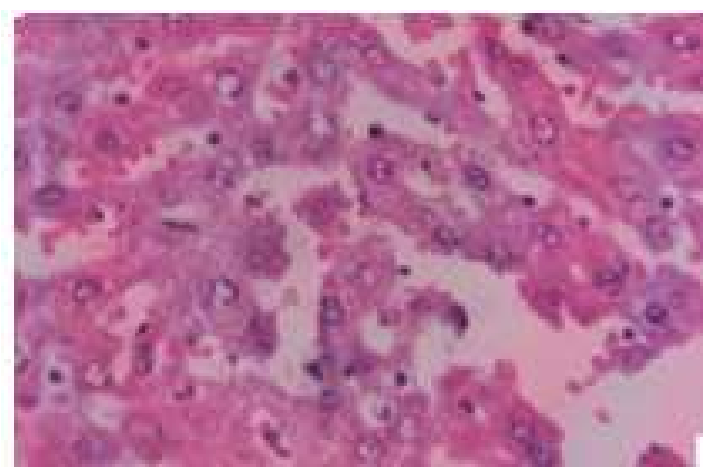

Fig. 5. Liver showed necrosis and degeneration of the hepatic cells and its nucleus with disorganization of the hepatic cords in non-immunized challenged mice. (Stain H\&E X 40)

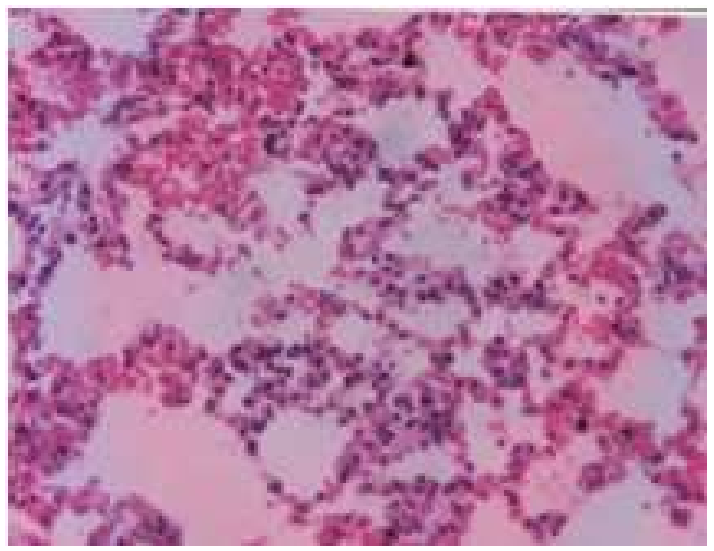

Fig. 6. Lung showed mild pneumonia where most of the alveoli are free in immunized challenged mice. (Stain H\&E X100)

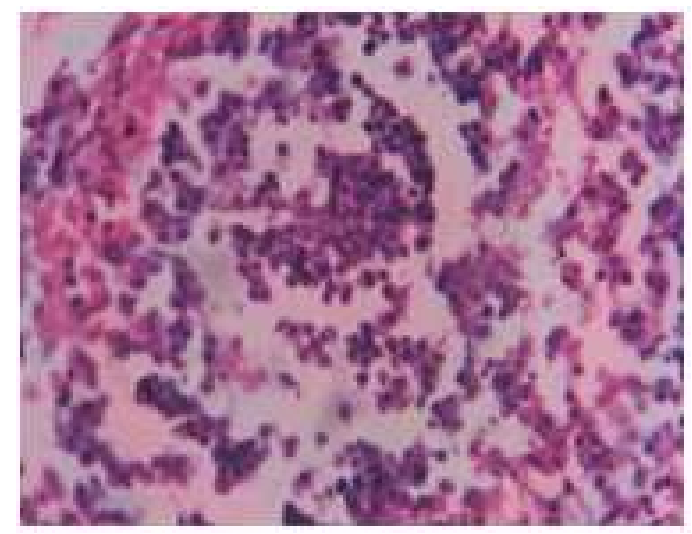

Fig. 7. Spleen showed mild hypoplasia of the white pulb in immunized challenged mice. (Stain H\&E X100) 


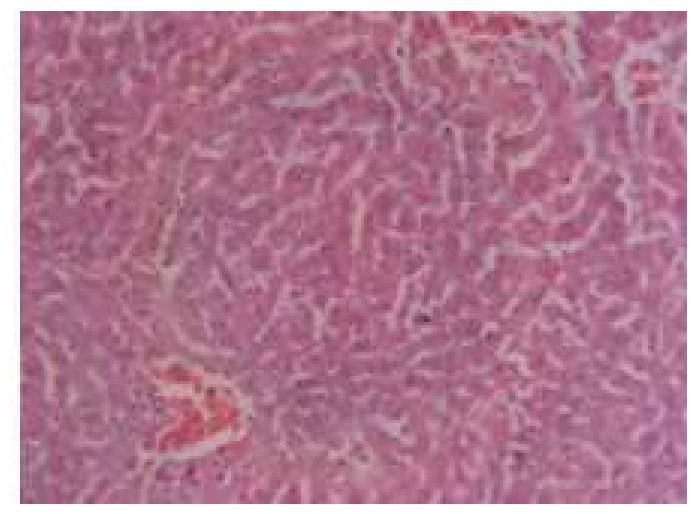

Fig. 8. Liver showed slight congestion of the central vein and hepatic cells appeared with normal arrangement in immunized challenged mice. (Stain H \& E X 40)

\section{DISCUSSION}

$K$. pneumoniae is an important Gram-negative opportunistic pathogen involved in hospital outbreaks of nosocomial infections including; acquired urinary tract infections, pneumonia, septicemia and infantile meningitis (Livermore, 2012). In addition, Klebsiella pneumoniaeis present in soil, faeces, water, among other locations within a dairy herd. The pathogen shows a high genetic diversity with different strains been isolated from several sources in dairy herds (Verbist et al., 2011). The control measure of klebsiellosis depends mainly upon the detection and treatment of infected domesticated animals. However, proper diagnosis confirmed by isolation and complete identification of the isolated microorganisms is important. In the present work, trials for the isolation of Klebsiella pneumoniae from diseased and apparently healthy farm animals were done for recognition of Klebsiella pneumoniae subspecies. A total of 246 samples collected from diseased farm animals were investigated bacteriologically. It was noticed from Table 2 out of 246 diseased animals, 62 animals revealed Klebsiella pneumoniae with overall incidence of $25.2 \%$. The results obtained in (Table 2) showed the relation between the kind of animal species examined and the prevalence of isolated Klebsiella pneumoniae subspecies (Gundogan and Avci, 2013).

It was found that the cows and sheep showed the highest prevalence of Klebsiella pneumoniae subspecies ( 25.6 and $24.2 \%$ respectively). Moreover, the prevalence of isolation from diseased goats and camels were 21.2 and 20.7\%, respectively (Table 2). In this aspect, Srinivasan et al. (2003) recovered Klebsiella pneumoniae from lambs with upper respiratory tract infection. Moreover Aher et al. (2012) recorded that the percentage of isolated Klebsiella pneumoniae was 5.6\% from caprine. In the present work trials for differentiation of various strains of Klebsiella pneumoniae isolates to subspecies revealed that the biochemical testing of 62 isolates of Klebsiella pneumonia from diseased animalsshowed that Klebsiella pneumonia subsp. pneumoniae was the most prevalent $44(17.9 \%)$ followed by Klebsiella pneumoniae subsp. Ozaenae $14(5.7 \%)$ and Klebsiella pneumoniae subsp. rhinoscleromatis $4(1.6 \%)$ (Table 2). This seems to coincide with observation of Munoz et al. (2007) who found that Klebsiella pneumoniae subsp. pneumoniae was predominant isolate ( $25 \%$ of cases) from 56 animal suffering from clinical mastitis. As shown in Table 2 it was concluded that in diseased cows the highest rate of isolation was obtained from faecal samples (32.1\%) followed by nasopharyngeal swabs $(28.7 \%)$, the lowest incidence could be isolated from milk samples (16.0\%). These results agreed to great extent with the finding of Hiroi et al. (2012) who isolated Klebsiella pneumoniae from nasal swabs and bronchial mucous collected from calves suffering from bronchopneumonia. Moreover, Munoz et al. (2007) reported that Klebsiella pneumoniae had been isolated from faecal samples of diarrhoeic calves.. As regard to sheep samples in this study Klebsiella pneumoniae was mainly predominant in faecal samples, nasopharyngeal swabs and milk samples 40.9, 17.4 and $14.3 \%$, respectively. Shahrzad et al. (2013) isolated Klebsiella pneumonia from lung of sheep suspected to be infected with pneumonia in an incidence of $15.09 \%$ and Gameel et al. (1991) isolated Klebsiella pneumoniae subsp. ozaenae from small nodules on chest wall and lungs of sheep slaughtered in Al-Ahsa Saudi Arabia. As shown in Table 2 it was clear that Klebsiella pneumoniae isolated from faecal samples, nasopharyngeal swabs and milk samples of examined goats were $31.8,26.3$ and 19.0 respectively. These finding support the statements of Suguna et al. (2012), who isolated Klebsiella pneumoniae from goat's milk.In the present study, the highest isolation rate of Klebsiella pneumoniae from camels samples was recorded from faecal samples $(40.0 \%)$, followed by nasopharyngeal swabs $(15.0 \%)$ and milk samples (5.6\%). In this aspect, Tibary and Anouassi (2000) reported that mastitis is a relatively infrequent disease in camelidae. Incidence of mastitis may increase in dairy camels due to hand milking and teat malformation. As shown in Table $\mathbf{2}$ and $\mathbf{3}$, it was noticed that there was a marked variation between incidences of Klebsiella pneumoniae subspecies in examined animals as regards to health condition. The frequency was greater among samples collected from diseased animals $25.2 \%$ as compared with apparently healthy one $5.5 \%$. Moreover there was great difference 
between the prevalence of Klebsiella isolated from various apparently healthy animal origins, as it was higher in sheep, followed by cow, goats and lastly camels with percentages of $8.5,5.5,4.1$ and $3.9 \%$, respectively (Table 3). These findings support the statement by Diego et al. (2013) who reported that, the natural flora of the intestine includes a large population of coliform bacteria including Klebsiella pneumoniae. Faeces are an important source of these organisms in the environment. This can become a serious problem as Klebsiella pneumoniae then commonly contaminate the water supply and other environment. Klebsiella pneumoniae are commonly found in environments where dairy cattle arekept. The biochemical testing of 11 isolates of Klebsiella pneumoniae from apparently healthy animals revealed their identification into Klebsiella pneumoniae subsp. pneumoniae (8) and Klebsiella pneumoniae subsp. ozaenae (3) On the other hand; it is of interest to notice that, Klebsiella pneumoniae subsp. rhinoscleromatis was not isolated from apparently healthy animals. Antibiotics are used extensively to prevent or to treat microbial infections in human and veterinary medicine. The most common response of the cell to antibiotics is to cease growing (bacteriostasis), but classes of compounds such as $\beta$ lactams, continued growth is permitted, with inhibition of the target in the organism leading indirectly to cell death. There has been growing concern about antimicrobial resistance for some years now (Diego et al., 2013). The antibiogram of pathogens could be variable from place to place and from case to another. This may be explained by the wide use of chemotherapeutic drugs and the variation in its use which may produce new resistant mutants. Multidrug resistant Klebsiella pneumonia strains are becoming an increasingly relevant medical problem worldwide with limited clinical treatment options (Arnold et al., 2011). For this reason, one of the steps in the controlling of klebsiellosis is the use of appropriate antibiotics. The kind of antibiotic should better be selected on the basis of its sensitivity which could be detected by laboratory examination (Balm et al., 2012). As shown in Table 4, the most effective antibiotics for Klebsiella pneumoniae subsp. were imipenem, ciprofloxacin, norfloxacin, gentamicin and kanamycin $(100 \%$ each).The superiority of flumequine and gentamicin for the in vitro action in Klebsiella pneumoniae was reported by Sarathbabu et al. (2012), who reported that all tested strains of Klebsiella pneumoniae were highly sensitive to gentamicin and flumequine. Also, Iroha et al. (2011) reported that all isolated Klebsiella pneumoniae subsp. pneumoniae strains were highly sensitive to enrofloxacin and norfloxacin. The results illustrated in Table 4 revealed that all Klebsiella pneumoniae subsp isolates were resistance to $\beta$-lactams antibiotics as cefoxitin, cefotaxime, cefoperazone, ceftazidime, ceftriaxone and aztreonam. These results agreed to great extent with the finding of Sarathbabu et al. (2012). Who reported that this species can become resistant to multiple $\beta$-lactams and particularly to aztreonam and ceftriaxone. While in the present study about $96.2 \%$ of all examined isolates were sensitive to amoxicillin/clavulanic acid and ticarcillin/clavulanic acid, these findings support the statement by Papagiannitsis et al. (2011) who reported that Clavulanic acid seemed to be active and to inhibit the $\beta$-lactams so combination of $\beta$-lactams withclavulanic acid seems to be effective. Capsular polysaccharide is one of the most important virulence factors of Klebsiella pneumoniae. The role of CPSs of Klebsiella pneumoniae has been proposed to have infection-promoting capabilities by inhibiting the release of acid phosphatase from lysosomal fractions of peritoneal macrophages to the extralysosomal fraction. Klebsiella pneumoniae strains constitutively express capsular polysaccharides that are critical for organism's ability to resist complement-mediated opsonophagocytic killing (Zou et al., 2011). Gel electrophoresis provides important and rapid method for molecular characterization of bacterial CPSs. The combined use of alcian blue and silver stain in the rapid detection of CPSs fragment separated by polyacrylamide gel electrophosrsis affords a 100 fold increase in sensitivity over previous methods. SDS-PAGE of extracted CPSs of examined Klebsiella pneumoniae subspecies strains revealed difference in profile (Fig. 1). The size and intensity of CPSs bands varied between the strains; the molecular weight of CPSs extracted from Klebsiella pneumoniae subsp. gave about 10 to 13 bands ranged in their molecular weights from $15.52 \mathrm{kDa}$ to 106.29 $\mathrm{kDa}$. These results nearly similar to that recorded by Yi-Jiun et al. (2013) who subjected CPSs isolated by classical methods from different bacteria to gel electrophoresis and stained them with alcian blue-silver stain. They found that all samples analyzed produced distinct pattern in gel electrophoresis and have molecular weight ranged from 10 to $100 \mathrm{kDa}$. The difference in behavior might be due to any of many variables involved in the strain, genotype and source of isolate and antigenic structure. Antimicrobial agents affect the production and structure of CPSs of Klebsiella pneumoniae as well as affect capsule size by promoting the release of CPSs from the bacterial cell. Klebsiella pneumoniae CPSs are involved in the immunoprotctive activity of antigen preparations extracted from this bacterium. Protective immunity and immunological characteristic of CPSs in experimental klebsiellosis in mice were one of the 
objectives of this study to evaluate the humoral immune response of mice immunized with capsular polysaccharides of Klebsiella pneumoniae using ELISA test. Data presented in Table 5 illustrated that significant increase in antibodies titre of antiKlebsiella pneumoniae was observed during different intervals post immunization, the level of antibody titer reached to the highest level at the 2 nd week post 1 st dose of immunization. This result similarly agrees with Zahran and Abdeen (2013), who reported that maximal anti-CPSs antibody titre were seen 14 days after a single dose of immunization. Liu et al. (2013), found that the immunization with CPSs evoked high titre of anti-CPSs antibodies, which conferred a significant degree of protection against Klebsiella pneumoniae. The present experimental study has demonstrated that CPSs of Klebsiella pneumoniae subspecies were capable of inducing protective immunity against virulent challenge with homologous and hetrologous strains in mice (Table 6). This result revealed that CPSs have high immune protective activity in mice due to their molecular conformation and other constituents of cell surface preparation as protein and LPSs act as adjuvant or carrier for CPSs (Zahran and Abdeen, 2013). It has been pointed that in vivo growth of bacteria and their reisolations from lung, liver and spleen in experimentally infected period of time are useful criteria by which protective immunity to Klebsiella is detected, Table 6. In this study it is noticed that the reisolation rates of Klebsiella pneumoniae subspecies from lung, liver and spleen of immunized mice and challenged with homologous and heterologous strains were (0 to $10 \%),(0$ to $10 \%)$ and (5 to $15 \%)$, respectively. Whereas the reisolation rates from the same organs of control mice were 50 to 60,50 to 60 and 65 to $80 \%$, respectively. The results of bioassay test and shedding of the organism come in agreement with results recorded by Liu et al. (2013) who showed that the protective capacity of CPSs can be reflected by the high quantitation of bacteria in the lung, liver and spleen of control than immunized mice. Moreover Yang et al. (2011) reported that CPS may be important for the establishmentof pneumonia, because active immunizationwith purified CPS protects experimental rats against lethal Klebsiella pneumonia. Klebsiella pneumoniae is particularly dangerous bacteria because once it has been established a disease it is extremely difficult to control. This would suggest that altered lung pathology during Klebsiella pneumoniae infections is the result of bacterial persistence and the action of somatic antigens such as CPSs, LPSs or CPSs-LPSs and protein complex (Chika et al., 2013). Microscopic examination of fixed and stained lung, spleen and liver tissues showed a marked difference in the pathology observed between control and immunized animal, whereas only minor pathological alteration were seen in these organs from immunized animals (Fig. 3-8). These results agree with Zahran and Abdeen (2013). who previously shown that anti-CPSs either passively transferred or engendered following immunization with CPSs were highly protective in mice model protection and were correlated with high titers of circulating anti-CPSs antibody. While immunization didn't prevent colonization of the lung following challenge, it did facilitate clearance of the invading organisms and prevent bacteraemia. This was an anticipated event, since anti-CPSs antibodies are known to promote the uptake and killing Klebsiella pneumoniae organism by polymorphnuclear leukocytes. The emergences of Klebsiella pneumoniae subspecies as a significant animal pathogen and its recognition as a zoonotic agent have stimulated research on technique for detection of infected herds. Bacterial culture can be used to establish a diagnosis of Klebsiella pneumoniae but this method was time consuming and some time fails especially in animal treated with antibiotic. The detection of antibodies to Klebsiella pneumoniae CPSs might overcome these problems inherent to this technique. In the present study, CPSs antigen based indirect ELISA to detect antibodies against Klebsiella pneumoniae subspecies in sera of examined animals was developed and compared with culture results (Table 7). It is clear that the standardized CPSs-ELISA gave satisfactory result using CPSs extracted from Klebsiella pneumoniae subsp. pneumoniae, Klebsiella pneumoniae subsp. ozaenae and Klebsiella pneumoniae subsp. rhinoscleromatis due to cross-reaction shared by CPSs between these Klebsiella pneumoniae subspecies. This may be related to presence of common epitope in CPSs of these Klebsiella pneumoniae subspecies and this cross reaction may also due to antigenic similarities in chemical composition and molecular conjugation (Liu et al., 2013). The sensitivity of ELISA using CPSs extracted from Klebsiella pneumoniae subspeciespneumoniae, Klebsiella pneumoniae subspecies ozaenae and Klebsiella pneumoniae subspecies rhinoscleromatis was 85.10, 79.79 and $81.91 \%$, respectively, while specificity was 93.48, 92.05 and $94.30 \%$, respectively (Table 8). This result confirmed that an immunological cross-reaction between CPSs from different bacterial species could not be completely ruled out (Zahran and Abdeen, 2013). ELISA significantly reduced the level of cross-reaction obtained with whole cell ELISA when sera to other capsular types were tested. However, cross-reactions were still observed with some capsular types, probaply due to presence of common epitopes in their capsule (Liu et al., 2013). Moreover our results coincided with 
Sikarwar and Batra (2011) who found that Patient infected with Klebsiella pneumonia mount an IGg antibody response to both homologous and hetrelogous CPSs antigens. ELISA using CPSs antigens could therefore serve as a valuable aid in serodiagnosis of Klebsiella pneumonia.

\section{CONCLUSION}

SDS-PAGE analysis showed that CPSs of Klebsiella pneumoniae subspecies contained wide variety of different molecular weights which ranged from $15.52 \mathrm{kDa}$ to $106.29 \mathrm{kDa}$ and gave $10-13$ bands. The most potent antibiotics showing $100 \%$ activity against Klebsiella pneumoniae subsp. isolated in this study were imipenem, ciprofloxacin, norfloxacin, gentamicin and kanamycin. By ELISA the highest immune response was obtained 14 days post 1 st dose of immunization with extracted CPSs of the three Klebsiella pneumoniae subspecies.

\section{REFERENCES}

Aher, T., A. Roy and P. Kumar, 2012. Molecular detection of virulence genes associated with pathogenicity of Klebsiella spp. Isolated from the respiratory tract of apparently healthy as well as sick goats. Israel J. Vet. Med., 67: 249-252.

Arnold, R.S., K.A. Thom, S. Sharma, M. Phillips and J.J. Kristie et al., 2011. Emergence of Klebsiella pneumoniae carbapenemase-producing bacteria. South Med. J., 104: 40-45. DOI: 10.1097/SMJ.0b013e3181fd7d5a

Balm, M.N.D., G. Ngan, R. Jureen, R.T.P. Lin and J. Teo, 2012. Molecular characterization of newly emerged $b_{\text {KPC-2-producing Klebsiella pneumoniae }}$ in Singapore. J. Clin. Microbiol., 50: 475-476. DOI: 10.1128/JCM.05914-11

Chander, Y., M.A. Ramakrishnan, N. Jindal, K. Hanson and S.M. Goyal, 2011. Differentiation of Klebsiella pneumonia and Klebsiella oxytoca by multiplex polymerase Chain reaction. Int. J. Appl. Res. Vet. Med., 9: 138-142.

Chika, E., I. Ifeanyichukwu, A. Michael and E. Charles, 2013. Susceptibility and detection of extended spectrum $\hat{I}^{2}$-lactamase enzymes from otitis media pathogens. Am. J. Infect. Dis., 9: 24-29. DOI: 10.3844/ajidsp.2013.24.29
Diego, B.N., M.V.S. Guiduce, F.F. Guimarães, D.F. Riboli and M.L.R.S. Cunha et al., 2013. Molecular epidemiology and extended-spectrum $\beta$-lactamases production of Klebsiella pneumoniae isolated from three dairy herds. Vet. Bras, 33: 855-859. DOI: 10.1590/S0100-736X2013000700005

Gameel, A.A., S.M. El-Sanousi, F. Al-Nawawi and M.O. Al-Shzly, 1991. Association of Klebsiella organisms with pulmonary lesions in sheep. Rev. Elev. Med. Vet. Des. Pays. Trop., 44: 161-164. PMID: 1818362

Gundogan, N. and E. Avci, 2013. Prevalence and antibiotic resistance of Extended-Spectrum BetaLactamase (ESBL) producing Escherichia coli and Klebsiella species isolated from foods of animal origin in Turkey. Afr. J. Microbiol. Res., 7: 40594064. DOI: 10.5897/AJMR

Hackstein, H., S. Kranz, A. Lippitsch, A. Wachtendorf and O. Kershaw et al., 2013. Modulation of respiratory dendritic cells during Klebsiella pneumonia infection. Respiratory Res., 14: 2-11. PMID: 24044871

Hiroi, M., F. Yamazaki, T. Harada, N. Takahashi, N. Iida and Y. Noda et al., 2012. Prevalence of extended-spectrum-lactamase-producing escherichia coli and Klebsiella pneumoniae in food-producing animals. J. Vet. Med. Sci., 74: 189-195. DOI: 10.1292/jvms.11-0372

Hotchkiss, R.S., G. Monneret and D. Payen, 2013. Immunosuppression in sepsis: A novel understanding of the disorder and a new therapeutic approach. Lancet Infect. Dis., 13: 260-268. DOI: 10.1016/S1473-3099(13)70001-X

Iroha, I.R., A.E. Oji, A.E. Nwakaeze, T.E. Ayogu and F.N. Afiukwa et al., 2011. Strains of Klebsiella Pneumoniae from intensive care unit producing CTX-M-15 extended spectrum beta lactamases. Am. J. Microbiol., 2: 35-39. DOI: 10.3844/ajmsp.2011.35.39

Joshi, S., M. Mudasir, D. Sharma and R. Singh, 2012. Histopathological study of cutaneous form of Avipoxvirus infection in Jungle crow (Corvus macrorhynchos) Vet. World, 5: 628-630. DOI: 10.5455/vetworld.2012.628-630

Liu, X., Y. Hao, S. Wang, A. Zhang, Y. Wang and Y. Guo et al., 2013. Assessment of immunogenicity of CP8, CLFA-FnBPB and CP8-CLFA-FnBPB antigens. Am. J. Anim. Vet. Sci., 8: 134-141. DOI: 10.3844/ajavsp.2013.134.141 
Livermore, D.M., 2012. Current epidemiology and growing resistance of gram-negative pathogens. Korean J. Int. Med., 27: 128-142. PMID: 22707882

Loschko, J., S. Heink, D. Hackl, D. Dudziak and W. Reindl et al., 2011. Antigen targeting to plasmacytoid dendritic cells via Siglec-H inhibits Th cell-dependent autoimmunity. J. Immunol., 187: 6346-6356. PMID: 22079988

Munoz, M.A., F.L. Welcome, Y.H. Schukken and R.N. Zadoks, 2007. Molecular epidemiology of two klebsiella pneumoniae mastitis outbreaks on a dairy farm in New York State. J. Clin. Microbiol., 45: 3964-3971. DOI: 10.1128/JCM.00795-07

Papagiannitsis, C.C., S.D. Kotsakis, E. Petinaki, A.C. Vatopoulos and E. Tzelepi et al., 2011. Characterization of metallo- $\beta$-lactamase VIM-27, an A57S Mutant of VIM-1 Associated with Klebsiella pneumoniae ST147. Antimicrob. Agents Chemother., 55: 3570-3572. DOI: 10.1128/AAC.00238-11

Renuka, R., R. Gangane, A.K. Oli and K.R. Chandrakanth, 2013. Prevalence of MDR-ESBL producing Klebsiella pneumoniae isolated from clinical Samples. J. Microbiol. Biotech. Res., 3: 32-39.

Sarathbabu, R., T.V. Ramani, B.K. Rao and S. Panda, 2012. Antibiotic susceptibility pattern of Klebsiella pneumoniae isolated from sputum, urine and pus samples. J. Pharma. Biol. Sci., 1: 4-9.

Shahrzad, A., F.S. Korani and A. Oryan, 2013. Pneumonia in slaughtered sheep in South-Western Iran: Pathological characteristics and aerobic bacterial aetiology. Vet. Ital, 49: 109-118. PMID: 23564592

Shon, A.S., R.P. Bajwa and T.A. Russo, 2013. Hypervirulent (hypermucoviscous) Klebsiella pneumonia: A new and dangerous breed. Virulence, 4: 107-118. PMID: 23302790

Sikarwar, A.S. and H.V. Batra, 2011. Identification of Klebsiella pneumoniae by capsular polysaccharide polyclonal antibodies. Int. J. Chem. Eng. Applic., 2: 130-134. DOI: 10.7763/IJCEA.2011.V2.89
Srinivasan, P., M. Jyue and R.A. Kumar, 2003. Bacteriological Studies of ovine pneumonia in an organized farm. Ind. Vet. J., 80: 311-313.

Suguna, M., R. Bhat and W.A.W. Nadiah, 2012. Microbiological quality evaluation of goat milk collected from small-scale dairy farms in Penang Island, Malaysia. Int. Food Res. J., 19: 1241-1245.

Tibary, A. and. A. Anouassi, 2000. Recent advances in camelidae reproduction: Lactation and udder diseases. J. Int. Vet. Inform.

Verbist, B., V. Piessens, V.A. Nuffel, D.L. Vuyst and M. Heyndrickx et al., 2011. Sources other than unused sawdust can introduce Klebsiella pneumoniae into dairy herds. J. Dairy Sci., 94: 2832-2839. PMID: 21605753

Yang, F.L., Y.L. Yang, P.C. Liao, J.C. Chou and K.C. Tsai et al., 2011. Structure and immunological characterization of the capsular polysaccharide of a pyrogenic liver abscess caused by Klebsiella pneumoniae: Activation of macrophages through Toll-like receptor 4.. J. Biol. Chem, 8: 1-18. PMID: 21478151

Yi-Jiun, P., L. Tzu-Lung, C. Yen-Hua, H. Chun-Ru and H. Pei-Fang et al., 2013. Capsular types of klebsiella pneumoniae revisited by wzc sequencing. PLoS ONE, 8: 1-13. DOI: 10.1371/journal.pone.0080670

Zahran, R.N. and E.A. Abdeen, 2013. Evaluation of the immune response to T. verrucosum vaccines. Am. J. Immunol., 9: 139-147. DOI: 10.3844/ajisp.2013.139.147

Zou, L.K., H.N. Wang, B. Zeng, A.Y. Zhang, J.N. Li et al., 2011. Phenotypic and genotypic characterization of $\beta$-lactam resistance in Klebsiella pneumoniae isolated from swine. Vet. Microbiol., 149: 139-146. DOI: $\quad 10.1016 /$ j.vetmic.2010.09.030, PMID: 21035968 